\title{
Effect of Urban Effluent on River Water Quality in the Niger Delta
}

\author{
Owhonda Ihunwo ${ }^{1,}$, Ekpendu Chisom ${ }^{1}$, Mmedorenyin Okon ${ }^{1}$, Okoroafor Isaiah ${ }^{2}$, \\ Charles Obunwo', Chinedu Mmom ${ }^{1}$ \\ ${ }^{1}$ Department of Geography and Environmental Management, University of Port Harcourt, Port Harcourt, Nigeria \\ ${ }^{2}$ Department of Chemical Sciences, Rivers State University, Port Harcourt, Nigeria
}

\section{Email address:}

owhonda.ihunwo@hotmail.co.uk(O. Ihunwo),chisomekpendu@gmail.com(E. Chisom),mmedorenyin.okon@gmail.com(M. Okon), isaiah.okoroafor1@ust.edu.ng(O. Isaiah),obunwo.charles@ust.edu.ng(C. Obunwo),prince.mmom@uniport.edu.ng(C.Mmom)

${ }^{*}$ Corresponding author

\section{To cite this article:}

Owhonda Ihunwo, Ekpendu Chisom, Mmedorenyin Okon, Okoroafor Isaiah, Charles Obunwo, Chinedu Mmom. Effect of Urban Effluent on River Water Quality in the Niger Delta. Frontiers in Environmental Microbiology. Vol. 4, No. 4, 2018, pp. 110-114. doi: $10.11648 /$ j.fem.20180404.13

Received: September 22, 2018; Accepted: October 4, 2018; Published: October 23, 2018

\begin{abstract}
Urban effluent polluted with sewage is a major source of pollution in developing countries, yet it is a line of study that is not properly explored. In this research, a river under influence from urban effluent was studied for four months, i.e. two seasons (dry season: February and March, wet season: April and May. Four sites along the river were identified for weekly sampling, with a distance from the start of the river as follows; site $1-100 \mathrm{~m}$, site $2-300 \mathrm{~m}$, site $3-500 \mathrm{~m}$ and site $4-1000 \mathrm{~m}$. In situ measurements of salinity were collected weekly. Samples were analysed for Dissolved Oxygen, Biochemical Oxygen Demand, phosphate and nitrate. Total Heterotrophic Bacteria (THB), Total Coliform Bacteria (TCB) and Faecal Coliform Bacteria (FCB) were also measured in water samples collected. These parameters were selected to access the activities of the microbial community in the water because of wastewater from the surrounding urban settlement on the watershed temporally and spatially. Results showed that the parameters studied changed in season and along the river. The dry season had significantly higher concentrations of parameters studied when compared to the wet seasons. Results also confirmed that the study river is polluted due to the urban effluent. This confirmation was attributed to the values of THB, TCB and FCB which were substantially high and varied from dry to wet season in the river.
\end{abstract}

Keywords: Wastewater, Sewage, River, Niger Delta, Biochemical Oxygen Demand, Faecal, Bacteria, Urbanisation

\section{Introduction}

Rivers are potential sources for freshwater and some flow through major cities and towns of the world. Examples of notable rivers include the Nile of Egypt, Indus of India, Rhine of Germany, Thames of London, Potomac of Washington DC (USA) and the Zambezi of Central Africa. UNESCO indicates that $48 \%$ of the world's population lives in towns and cities and by 2030 , this figure is likely to rise to about $60 \%$ [1]. Where good waste management is lacking, urban areas are among the world's most life-threatening environments [1].

Some authorities in rapidly urbanizing cities in Africa are grappling with the increased demand for social amenities as water, refuse collection, sanitation facilities, decent housing and security. In some cities in Africa, the demand for social amenities has outstripped the ability of city authorities to provide them [2].

Some rivers in urban areas are affected by municipal waste which washes into the river. In areas with poor sanitation or lack of wastewater treatment facilities, these runoffs are highly polluted and when they make their way into the rivers, they also serve as a major pollutant in the river. Research has shown that urban effluent into water bodies have the ability to change the physical and chemical conditions of a river, thereby leading to a contaminated state [3]. Hardoy, et al 2001 indicated that river pollution from city-based industries and untreated sewage can lead to serious health problems in 
settlements downstream.

This study is designed to investigate the effect of sewage runoff from an urban community in Niger Delta on the river water quality of our study river. The objective of this study is to collect water samples from different sites on the river and to assess for certain parameters that will indicate the presence and activities of sewage on the river of study.

\section{Methods and Materials}

\subsection{Study Area}

This study was carried out on a $1.4 \mathrm{~km}$ stretch of a freshwater stream of Anya-Ogologo River which runs through Mgbosimini community of Obio/Akpor, in the Niger Delta Region of Nigeria. This river was selected for study because it runs through this community and empties into a larger brackish river. This community does not have a proper municipal waste management system. By investigations, most of the riverfront dwellers do not have a proper sewage system, therefore, there is a direct input of sewage in the river.

\subsection{Sample Collection and Analysis}

Four sample points were selected on the river (Table 1). Weekly sampling was carried out for four months to represent the dry and wet seasons of the region; February and March (dry season), April and May (wet season).

Table 1. Site ID with GPS location and distance apart from each sample site.

\begin{tabular}{lll}
\hline Site ID & GPS location & Distance from the start \\
\hline Site 1 & $4^{\circ} 48^{\prime} 27.6^{\prime \prime} \mathrm{N} 6^{\circ} 58^{\prime} 03.0^{\prime \prime} \mathrm{E}$ & 100 meters \\
Site 2 & $4^{\circ} 48^{\prime} 26.8^{\prime \prime} \mathrm{N} 6^{\circ} 58^{\prime} 02.0^{\prime \prime} \mathrm{E}$ & 300 meters \\
Site 3 & $4^{\circ} 48^{\prime} 24.0^{\prime \prime} \mathrm{N} 6^{\circ} 58^{\prime} 02.0^{\prime \prime} \mathrm{E}$ & 500 meters \\
Site 4 & $4^{\circ} 48^{\prime} 14.0^{\prime \prime} \mathrm{N} 6^{\circ} 58^{\prime} 01.0^{\prime \prime} \mathrm{E}$ & 1000 meters \\
\hline
\end{tabular}

In situ measurements were carried out for dissolved oxygen, salinity and electric conductivity on each sample point on the river using a multimeter; Ip67 Combo pH/Conductivity/Salinity/DO Meter Model 8603.

Sterile plastic bottles were used to collects samples for analysis for sulphate and nitrate. Samples were also collected for microbial analysis of the following parameters; Total Heterotrophic Bacteria (THB), Total Coliform Bacteria (TCB) and Fecal Coliform Bacteria (FCB). 300ml amber bottles were used to collect samples for Biochemical Oxygen Demand. Samples taken to the lab were stored in an ice box and transported to the laboratory for analysis.

Biochemical Oxygen Demand (BOD) was determined using titrimetric analysis under the Winkler's Method [5].
The dissolved oxygen in the sample is then fixed by adding a series of reagents that form an acid compound that is then titrated with a neutralizing compound that results in a colour change.

Total Coliform Bacteria (TCB) and Fecal Coliform Bacteria (FCB) were analyzed using the Membrane Filtration method. The technique used for analyzing for Total Heterotrophic Bacteria (THB) was the Peel Plate Method 10289 in which the Heterotrophic Plate Count test (HPC) was carried out as adapted from standard methods for the examination of water and wastewater section 9215 [6]. The peel plate procedure measures the total heterotrophic bacteria numbers in water. the procedure is based on R2A agar from standard methods for the examination of water and wastewater. The procedure contains the redox indicator substrate 2,3,5-triphenyl tetrazolium chloride (TTC). TTC is reduced by most bacteria to form red colonies. The red colonies are easier to see against the off-white background. After incubation, the colonies are counted, and each colony is counted as colony forming unit (CFU) [7].

Nitrate and Phosphate were analysed spectrophotometrically. For Nitrate, the $\mathrm{pH}$ of water samples was adjusted to $\mathrm{pH} 2$ with concentrated sulphuric acid (approximately $2 \mathrm{~mL}$ per litre). Before the laboratory analyses, the sample temperature was increased to room temperature and the $\mathrm{pH}$ was adjusted to $\mathrm{pH} 7$ using $5-\mathrm{N}$ sodium hydroxide solution. Cadmium metal reduces nitrate in the sample to nitrite. The nitrite ion reacted in an acidic medium with sulfanilic acid to form an immediate diazonium salt. The salt couples with gentisic acid to form an amber coloured solution which is then measured with a wavelength of $500 \mathrm{~nm}$ in a spectrophotometer [8]. The Phosver 3 with Acid Persulfate Digestion Method 8190 was used in the analysis for phosphate. Pre-treatment of the sample with acid and heat provides the conditions for hydrolysis of the inorganic forms of phosphate to the organic form. The organic phosphates where then converted to Orthophosphates by heating with acid and persulfate. Orthophosphates reacts with molybdate in an acid medium to produce a mixed phosphate/molybdenum complex which is then measured at a wavelength of $880 \mathrm{~nm}$ with a spectrophotometer [9].

Data were analyzed for spatial and temporal variation in the river to assess changes along certain points on the river and in season. Data were tested for normality and ANOVA was performed to compare changes using Sigmaplot [10].

\section{Results and Discussion}

Results of the analysis can be seen in tables 2 and 3 below.

Table 2. Temporal variation of salinity, phosphate, nitrate, dissolved oxygen, biochemical oxygen demand, total heterotrophic bacteria (THB), total coliform bacteria (TCB), and faecal coliform bacteria (FCB) in all the sample sites.

\begin{tabular}{|c|c|c|c|c|c|}
\hline \multirow{3}{*}{ Parameter } & \multicolumn{4}{|l|}{ Site 1} & \multirow{3}{*}{ p value } \\
\hline & \multicolumn{2}{|l|}{ Dry Season } & \multicolumn{2}{|c|}{ Wet Season } & \\
\hline & Mean & St. dev. & Mean & St. dev. & \\
\hline Salinity(ppt) & 0.21 & 0.01 & 0.2 & 0.05 & $>0.050$ \\
\hline Phosphate(mg/l) & 3.67 & 0.21 & 0.4 & 0.17 & $<0.001$ \\
\hline $\operatorname{Nitrate}(\mathrm{mg} / \mathrm{l})$ & 6.7 & 0.53 & 0.63 & 0.51 & $<0.001$ \\
\hline
\end{tabular}




\begin{tabular}{|c|c|c|c|c|c|}
\hline \multirow{3}{*}{ Parameter } & \multicolumn{4}{|l|}{ Site 1} & \multirow{3}{*}{ p value } \\
\hline & Dry Season & & Wet Seas & & \\
\hline & Mean & St. dev. & Mean & St. dev. & \\
\hline $\mathrm{DO}(\mathrm{mg} / \mathrm{l})$ & 1.65 & 0.13 & 1.75 & 0.24 & $>0.050$ \\
\hline BOD (mg/l) & 801.45 & 310.69 & 1118.1 & 110.03 & $>0.050$ \\
\hline THB & 6406.25 & 308.47 & 2977.5 & 638.77 & $<0.050$ \\
\hline TCB & 5562.25 & 120.86 & 1972.75 & 125.34 & $<0.001$ \\
\hline FCB & 1038.5 & 79.11 & 474.75 & 115.87 & $<0.001$ \\
\hline \multirow{3}{*}{ Parameter } & Site 2 & & & & \multirow{3}{*}{ p value } \\
\hline & Dry Season & & Wet Seas & & \\
\hline & Mean & St. Dev & Mean & St. dev. & \\
\hline Salinity(ppt) & 0.37 & 0.03 & 0.27 & 0.08 & $>0.050$ \\
\hline Phosphate(mg/l) & 3.47 & 0.55 & 0.5 & 0.27 & $<0.050$ \\
\hline Nitrate $(\mathrm{mg} / \mathrm{l})$ & 17.9 & 2.43 & 0.87 & 0.06 & $<0.001$ \\
\hline $\mathrm{DO}(\mathrm{mg} / \mathrm{l})$ & 0.26 & 0.1 & 1.7 & 0.87 & $<0.050$ \\
\hline BOD (mg/l) & 117.7 & 76.7 & 119.83 & 22.17 & $>0.050$ \\
\hline THB & 6063 & 194.55 & 3173 & 883.61 & $<0.001$ \\
\hline TCB & 4539.75 & 355.5 & 1121.5 & 252.57 & $<0.001$ \\
\hline FCB & 442.75 & 21.41 & 203 & 97.96 & $<0.050$ \\
\hline \multirow{3}{*}{ Parameter } & Site 3 & & & & \multirow{3}{*}{ p value } \\
\hline & Dry Season & & Wet Seas & & \\
\hline & Mean & St. Dev & Mean & St. dev. & \\
\hline Salinity(ppt) & 0.973 & 0.45 & 0.84 & 0.43 & $>0.050$ \\
\hline Phosphate(mg/l) & 4 & 0.44 & 1.44 & 0.39 & $<0.050$ \\
\hline Nitrate $(\mathrm{mg} / \mathrm{l})$ & 9.53 & 1.22 & 1.23 & 0.25 & $<0.001$ \\
\hline $\mathrm{DO}(\mathrm{mg} / \mathrm{l})$ & 1.65 & 0.3 & 2.625 & 0.359 & $<0.050$ \\
\hline BOD (mg/l) & 818.075 & 46.479 & 828.775 & 201.899 & $>0.050$ \\
\hline THB & 4342.5 & 189.451 & 2364.5 & 959.222 & $<0.050$ \\
\hline TCB & 1365 & 170 & 172 & 58.72 & $<0.001$ \\
\hline $\mathrm{FCB}$ & 285.25 & 30.999 & 102.75 & 24.865 & $<0.001$ \\
\hline \multirow{3}{*}{ Parameter } & Site 4 & & & & \multirow{3}{*}{ p value } \\
\hline & Dry Season & & Wet Seas & & \\
\hline & Mean & St. dev. & Mean & St. dev. & \\
\hline Salinity(ppt) & 3.09 & 0.05 & 2.14 & 0.86 & $>0.050$ \\
\hline Phosphate(mg/l) & 3.57 & 0.31 & 0.97 & 0.5 & $<0.050$ \\
\hline Nitrate(mg/l) & 7.4 & 1.06 & 0.43 & 0.21 & $<0.001$ \\
\hline $\mathrm{DO}(\mathrm{mg} / \mathrm{l})$ & 1.58 & 0.26 & 3.55 & 0.4 & $<0.050$ \\
\hline BOD (mg/l) & 1119.38 & 11.79 & 284.88 & 36.68 & $<0.050$ \\
\hline THB & 1000.25 & 82.1 & 274.75 & 46.44 & $<0.001$ \\
\hline TCB & 942.5 & 17.08 & 99.25 & 7.63 & $<0.001$ \\
\hline FCB & 91.5 & 12.92 & 25.5 & 3.32 & $<0.001$ \\
\hline
\end{tabular}

St. dev. $=$ Standard deviation, $\mathrm{DO}=$ Dissolved Oxygen, $\mathrm{BOD}=$ Biochemical Oxygen Demand, $\mathrm{THB}=$ Total Heterotrophic Bacteria, $\mathrm{TCB}=\mathrm{Total}$ Coliform Bacteria, FCB = Faecal Coliform Bacteria.

Table 3. Spatial variation of salinity, phosphate, nitrate, dissolved oxygen, biochemical oxygen demand, total heterotrophic bacteria (THB), total coliform bacteria (TCB), and faecal coliform bacteria (FCB) in all the sample sites.

\begin{tabular}{|c|c|c|c|c|c|c|c|c|c|}
\hline \multirow{2}{*}{ Parameter } & \multicolumn{2}{|l|}{ Site 1} & \multicolumn{2}{|l|}{ Site 2} & \multicolumn{2}{|l|}{ Site 3} & \multicolumn{2}{|l|}{ Site 4} & \multirow{2}{*}{ p value } \\
\hline & Mean & Std. Error & Mean & Std. Error & Mean & Std. Error & Mean & Std. Error & \\
\hline Salinity(ppt) & 0.20 & 0.01 & 0.32 & 0.03 & 0.91 & 0.15 & 2.62 & 0.27 & $<0.001$ \\
\hline Phosphate(mg/l) & 2.03 & 0.97 & 2.10 & 0.92 & 2.68 & 0.84 & 2.30 & 0.79 & $>0.050$ \\
\hline Nitrate(mg/l) & 3.80 & 3.62 & 9.28 & 9.92 & 5.25 & 4.89 & 3.78 & 4.04 & $>0.050$ \\
\hline DO (mg/l) & 1.70 & 0.07 & 0.99 & 0.34 & 2.14 & 0.21 & 2.56 & 0.39 & $>0.050$ \\
\hline BOD (mg/l) & 959.78 & 96.96 & 118.76 & 18.48 & 823.43 & 135.75 & 202.13 & 91.99 & $<0.001$ \\
\hline THB & 4691.88 & 668.45 & 4618.00 & 584.93 & 3353.50 & 436.97 & 637.50 & 138.83 & $<0.001$ \\
\hline FCB & 756.63 & 111.38 & 322.88 & 50.91 & 194.00 & 35.70 & 58.50 & 12.85 & $<0.001$ \\
\hline
\end{tabular}

Std. Error $=$ Standard Error, DO $=$ Dissolved Oxygen, BOD $=$ Biochemical Oxygen Demand, $\mathrm{THB}=$ Total Heterotrophic Bacteria, $\mathrm{TCB}=$ Total Coliform Bacteria, FCB = Faecal Coliform Bacteria.

The results revealed that the concentrations on parameters assessed varied spatially from site 1 to site 4 and temporally from the dry months (February and March) to the wet months (April and May). Phosphate in the river was higher in the dry months compared to the wet months (Table 2). Phosphorus is essential for the growth of aquatic plants in a stream. However, at certain concentrations, phosphate encourage the growth of eutrophication in rivers (Jordan, et al., 2017). Research has shown that phosphate increase in a fluvial system can be attributed to discharge from both urban, such 
as wastewater and sewage effluent and agricultural sources from phosphorus-enriched soils [11]. From the wet to dry season at each sample point, phosphate concentration was statistically significantly different $(p<0.05)$ (Table 2$)$. However, phosphate did not show any statistically significant difference when compared spatially from site 1 to site 4 $(\mathrm{p}>0.05)$ (Table 3$)$.

Nitrate occurs naturally in aquatic systems; aquatic organisms add to the concentration of nitrate in a river by excreting waste high in ammonia which is then converted to nitrate and further to nitrite by certain microbial species. Nitrate, like phosphate, in excess can lead to a eutrophic condition in a river. Eutrophication can also lead to a reduction in the quantity of dissolved oxygen is present in the river, in turn reducing the rate of conversion of ammonia to nitrite and to nitrate, leaving a high concentration of nitrite and ammonia, which are more toxic in the river (Suthar, et al., 2010). The reduction in the quantity of dissolved oxygen in the river can lead to an inhabitable condition for aquatic lives. In this study, the concentration of nitrate was higher in the dry months when compared to the wet months. There is a statistically significant difference $(p<0.001)$ in nitrate concentration between the dry and wet months. Spatial variation of nitrate concentrations did not show any statistically significant difference from site 1 to site 4 . Therefore, there is a uniform distribution of nitrate from site 1 to site 4 .

Dissolved oxygen plays an important role in the aquatic system, the quantity of oxygen dissolved in water is a major indicator of the quality of a river. Organisms that live in aquatic systems depend on oxygen for their survival, therefore, when dissolved oxygen in water drops below a certain concentration, the aquatic life in the water struggles for survival. The amount of dissolved oxygen in a pristine freshwater usually range from $7.56 \mathrm{mg} / \mathrm{L}$ at $30^{\circ} \mathrm{C}$ to 14.62 $\mathrm{mg} / \mathrm{L}$ at $0^{\circ} \mathrm{C}$ [13], therefore, the temperature also affects the quantity of oxygen that dissolves in the water. Research has shown that the quantity of oxygen in a river is directly proportional to the water quality index of a river [14]. Impurities such as dissolved minerals reduce the quantity of oxygen that dissolves in water. The growth of algae in a river due to the input of nitrogen causes a drop in the quantity of oxygen dissolved in the river. As the algae die and decompose, there is a further depletion of oxygen in the river, therefore, resulting in a low concentration of oxygen insufficient of aquatic lives to survive. In this study, except for site 1 which didn't show a statistically significant difference $(p>0.05)$ between the dry and wet season, each sample showed an increase in DO as the rains started to fall which can be related to a drop in temperature in the river due to an increased rainfall. There is a statistically significant difference observed from the wet to dry to the wet season on site 2, 3 and $4(\mathrm{p}<0.05)$. Observing the spatial data (Table 3 ), there is a relationship between an increase of nitrate in the river at site 2 and an increased nitrogen at this point. Mean values of biochemical oxygen demand showed a statistically significant difference $(\mathrm{p}<0.05$ between the wet and dry season only at site 4 . However, spatial analysis of BOD in the river showed a statistically significant difference $(\mathrm{p}<0.001)$ from site 1 to site 4. BOD is a measure of microbial activities that consume dissolved oxygen in the water. The process of degradation of organic matter by microorganisms by converting them to carbon dioxide and water lead to the depletion of oxygen in the water [15]. Some of these organic matters can come from sewage, agricultural runoff, and domestic and industrial wastewater. When organic matters are fed into an aquatic system, the bacteria live and multiply. Our study showed high levels of microbial activities due to the evidently high levels of BOD recorded. This is due to the direct input of untreated sewage to the river at the various sites on the river.

Sewage input in a river accounts for the bacterial count in the river and the types of bacteria that is found in the river. This can include faecal coliform bacteria, which live in high number in the intestine of warm- and cold-blooded animals. Therefore, their presence in aquatic systems is an indication that that river is contaminated with the human waste material. Although they are harmless in the human intestine, their presence in a river is usually associated with the presence of pathogens such as; typhoid fever, viral, and bacterial gastroenteritis and hepatitis A [16]. In relation to our study, there was a high count of THB measured in the river. There was also a statistically significant difference of THB observed between the dry and the wet season at each sample point (site1: $p=<0.05$, site 2,3 and $4: p=<0.001$ ) (Table 2), with higher counts recorded in the dry season as compared to the wet season. TCB and FCB were also higher in the dry season compared to the wet season at each site (Table 2). Spatial analysis showed a reducing trend of microbial activities from site 1 to site 4 on the river with a statistically significant difference $(\mathrm{p}=<0.001)$. The reduced microbial activity is in relation to an increase in salinity observed along the river from site 1 to site 4 . Research has shown that microbial activity is inversely proportional to an increase in salinity in the aquatic system [17].

\section{Conclusion}

The effect of sewage effluent in our study river is evident in the present poor water quality state in which the river exists at present. The combined effects of nutrient input, biochemical and microbial activities in this river put the water in a state which is inhabitable for aquatic lives which should exist in this river. For this river to be of a comfortable state for aquatic organisms to survive and anthropogenic usage, there needs to be a mitigation plan and a management system designed by the municipality together with proper monitoring procedure and structure. Such mitigation plans and management systems must include the development of proper sewage systems or wastewater treatment system within this municipalities.

This river is, therefore, not suitable for human consumption. There is also a possibility that some aquatic organisms will find survival difficult under these conditions. 
In situations where fishes and other aquatic organisms are eaten from this river, there is also a possibility of bioaccumulation of certain chemicals such as pharmaceuticals and which research has shown to exist in sewage and urban effluent.

This research paper, therefore, recommends a more detailed assessment of this river which will look into the effect of the urban effluent into this river on the survival of some aquatic organisms. It is also necessary to assess the concentrations of chemicals of emerging concerns such as pharmaceuticals in this study river.

\section{Acknowledgements}

The research team wishes to thank the supervisor of this project, Professor Charles Obunwo from Rivers State University, Nigeria, and Professor Prince Chinedu Mmom from the University of Port Harcourt. The team also appreciates the support of Chinwe Elenga together with other field and laboratory personnel of the Niger Delta Aqua Research Group, NDARG.

\section{References}

[1] UNESCO, "Water for People, Water for Life," 2003.

[2] O. Adepoju and F. Adetoye, "Urban Research in Nigeria," Inst. français Rech. en Afrique, pp. 1-3, 2018.

[3] J. Zhang, Z. Wei, H. Jia, and X. Huang, "Factors influencing water quality indices in a typical urban river originated with reclaimed water,” Front. J. Environ. Sci. Eng., vol. 11, no. 4, p. 8, 2017.

[4] J. E. Hardoy, D. Mitlin, and D. Satterthwaite, Environmental problems in an urbanizing world: finding solutions for cities in Africa, Asia and Latin America. London : Earthscan, 2001.

[5] S. W. Mckenzie, "FIVE-DAY BIOCHEMICAL OXYGEN DEMAND," vol. 7, pp. 1-21, 2003.
[6] Hach Company/ Hach Lang GmbH, "Heterotrophic Bacteria. Plate Count Agar, Method 8241,” 2015.

[7] Hach Company/ Hach Lang GmbH, "Coliforms, Total, Fecal and E. coli. m-Endo Broth Ampule, Method 8074,” 2017.

[8] Hach Company/ Hach Lang GmbH, "Nitrate. Cadmium Reduction Method Method 8039," 2014.

[9] Hach Company/ Hach Lang GmbH, "Phosphorus, Total. USEPA1 PhosVer ${ }^{\circledR}, 3$ with Acid Persulfate Digestion Method Method 8190," 2017.

[10] Systat Software. Inc., "SigmaPlot for Windows version 12.5," 2011.

[11] T. E. Jordan, D. E. Weller, and C. E. Pelc, "Effects of Local Watershed Land Use on Water Quality in Mid-Atlantic Coastal Bays and Subestuaries of the Chesapeake Bay," Estuaries and Coasts, pp. 1-16, 2017.

[12] S. Suthar, J. Sharma, M. Chabukdhara, and A. K. Nema, "Water quality assessment of river Hindon at Ghaziabad, India: impact of industrial and urban wastewater," Environ. Monit. Assess., vol. 165, no. 1, pp. 103-112, 2010.

[13] MPCA, "Low Dissolved Oxygen in Water Causes, Impact on Aquatic Life - An Overview," no. February 2009.

[14] P. R. Kannel and S. Lee, "Application of Water Quality Indices and Dissolved Oxygen as Indicators for River Water Classification and Urban Impact Assessment," Environ. Monit. Assess., vol. 132, pp. 93-110, 2007.

[15] C. C. Hach, L. K. J. Robert, and C. R. Gibbs, Introduction to Biochemical Oxygen Demand, no. 7. 1997.

[16] K. Manoj and P. Avinash, "A review of permissible limits of drinking water," Indian J. Occup. Environ. Med., vol. 16, no. 1, pp. 1-6, 2012.

[17] A. A. Bordalo, R. Onrassami, and C. Dechsakulwatana, "Survival of faecal indicator bacteria in tropical estuarine waters (Bangpakong River, Thailand)," J. Appl. Microbiol., vol. 93, pp. 864-871, 2002. 